KEYWORDS

Economic crisis

Financial crisis

Economic policy

Development models

ECLAC

Economic development

Latin America

Gert Rosenthal

Executive Secretary of ECLAC,

1988-1997

Current Permanent Representative

of Guatemala at the United Nations

- grosenthal61@hotmail.com
CEPAL REVIEW 100 APRIL 2010

\section{The financial and economic crisis of 2008 and its repercussions on economic thought}

\author{
Gert Rosenthal
}

$\mathrm{T}$

he financial and economic crisis of 2008 had multiple consequences in Latin American and Caribbean countries. It disrupted economic performance and called into question the paradigms that had steered economic policy in most countries; and it also exacerbated the growing divergences in points of view that were emerging before the crisis, some of which are ideological, while others reflect different approaches to economic strategies. The differentiating factors include: the role of the State and its relation to the market; and the nature and scope of participation in the global economy. This article addresses some of these divergences, the tensions they generate, and what the future holds for cooperation within Latin America. It also points out that in this new scenario, characterized by some perplexity, issues inherent to the work of ECLAC are clearly emerging. 


\section{I}

\section{Introduction}

Without doubt, the financial and economic crisis of 2008, preceded by the twin crisis that affected the energy and fuel markets, will be remembered as a watershed event, because it revealed the vulnerabilities of globalization, pushed the global economy to the brink, inflicted major hardship on tens of millions of human beings and also exacerbated old disputes and tensions over how to approach development. The crisis has spawned an abundant literature in academic circles, international organizations and even in the media. In ECLAC itself, valuable work has been done in analysing the origin of the crisis, along with its propagation, impact and potential consequences for the future (ECLAC, 2009a, 2009b, 2009c and 2009d). Perhaps less studied have been the disputes and tensions that that crisis intensified in the economic domain; and these in particular will form the central focus of this article from the Latin American standpoint. In general, the debate revolves around the role of the State in the various development paradigms; more specifically, two areas will be highlighted: how to address social equity and the growing polarization in multilateral forums.

\section{II}

\section{The immediate backdrop}

The outbreak of the financial crisis in 2008 not only changed the performance of the region's economies, but tested economic policy paradigms that had been in place for a long time, albeit with contents and intensities that differed from one country to another. Thus, by having differentiated repercussions on different groups within each country, and also between countries, the crisis generated or exacerbated pre-existing tensions, influencing - among other things - the content, scope and tone of international relations. Above all, differentiated responses intensified the debate on how to overcome the current predicament and be in a position to fulfil the universal aspirations so eloquently expressed in the Millennium Development Goals.

From that standpoint, many analysts have noted, not without a certain perverse satisfaction, that following decades of listening to "sermons" from the world's main economic centres, including multilateral financial institutions, on how to responsibly and consistently conduct macroeconomic management to avoid the periodic crises that characterized the region, this time the scenario was inverted and the former preachers were shown to be irresponsible. Meanwhile, their former Latin American pupils, who in general acted professionally, were those who had to pay for the havoc caused by a crisis that developed in the very heart of capitalism, without bearing the least responsibility for creating it. For a region that has often concealed its economic mismanagement by blaming its unsatisfactory performance on international phenomena, the "blame" on this occasion undeniably could be assigned abroad.

In the light of the crisis, many analysts, both individual and institutional, including the Economic Commission for Latin America and the Caribbean (ECLAC) itself, have felt vindicated in their analysis of recent years. Firstly, they have persistently warned about the unsustainability of the financial imbalances that were developing in the world economy, especially between the United States and some of its surplus trading partners. ${ }^{1}$ Secondly, they have questioned the economic paradigm that has been in vogue since the 1980s, specifically because of its overvaluation of the role of the market and its undervaluation of the role of the State in economic and social performance.

Over the last 20 years, ECLAC has contributed to the debate on development paradigms, strengthening its vocation as an organization that generates heterodox positions, questioning or supporting the postulates

\footnotetext{
${ }^{1}$ See, among others, ECLAC (2006a, p.31; 2007a, pp.35 and 36; and 2007b, p.24).
} 
of various orthodoxies, and addressing the specifics and characteristic features of development patterns in the region and its various types of economies. ${ }^{2}$ This vocation has been particularly relevant since 1990 in the economic debate on current models, and the critique made by various sectors on the mechanical way in which its precepts were being applied. ${ }^{3}$ In its most simple terms, a central thrust of the analysis revolves around the idea that market signals alone would not resolve everything; what was required was a judicious combination of market and State to achieve the multiple objectives of development, including economic growth, greater equity, financial stability and environmental sustainability.

The trigger for the great financial crisis of 2008, which can largely be blamed on a market that functioned deficiently (to say the least) and the virtual absence of the State in fulfilling its regulatory role, will clearly encourage the agnostics of pure orthodoxy to persist in seeking devices to enable them to promote development in an increasingly complex and agitated international setting.

\section{III}

\section{Tensions and polarization of positions}

The panorama becomes even more complicated, however, when one takes account of the increasing heterogeneity of approaches emerging in Latin America, not only on how to address economic strategies and policies, but on how to visualize the role of the region in the international setting, compounded by differences in political agenda that reflect the highly diverse situations prevailing in the different countries. The main dividing line in the economic debate precedes the 2008 crisis and stems from the way the different countries seek to interact with the international economy. In schematic terms (reality is always more complex and nuanced), the two extremes in a wide spectrum of positions would be as follows: at one end are countries that are intensively committed to openness and trade liberalization (but not all of them accepted financial liberalization at the same time, as postulated by the paradigm then in vogue). These countries sought to gain access to the main developed markets, particularly the United States, through free trade agreements. By definition, these countries are willing to largely submit to the dictates of the market economy.

At the other end of the spectrum are countries that seek greater autonomy - from the international economy and the United States in particular - and less dependence on market signals. Indeed, the then

\footnotetext{
${ }^{2}$ See ECLAC (1990, 1994a, 1996 and 1998) and Torres (2006).

${ }^{3}$ For a penetrating analysis of the differences between the paradigm that was current in the 1990s and that proposed by ECLAC, see the interview of Fernando Fajnzylber by Fernando Fernández (Fernández, 1994, pp. 207-209)
}

entitled "Bolivarian Alternative for the Americas (ALBA)", signed between Cuba and the Bolivarian Republic of Venezuela in December 2004, was initially proposed as an alternative to the Free Trade Agreement of the Americas (FTAA), which, following the First Summit of the Americas, held in Miami in December 1994, aimed to create a hemisphere-wide free-trade zone (although specifically excluding Cuba for well-known reasons).

As is common knowledge, the latter initiative never materialized, owing to resistance by several of the region's countries, each motivated by its own reasons and interests. But the failure of the original initiative gave rise to a set of free trade agreements of limited geographic scope, which were added to the North American Free Trade Agreement (NAFTA) signed earlier between Mexico, Canada and the United States. Agreements of this type have been implemented in Chile, the Central American countries, the Dominican Republic and Peru, with Colombia and Panama still waiting to join them. The dividing line between countries that maintain free trade agreements (FTAs) with the United States and those that propose an alternative, gained an additional ideological and political dimension in the way the different countries interacted with United States, which the Internet portal of ALBA itself describes - not without an offensive bias - as "an imperialist proposal for domination confronted by a patriotic proposal of liberalization" (Rossi, 2009).

Some analysts have also added a geographic dimension to this sharp economic, political and ideological division. Firstly they point out that Latin 
American countries in the Pacific Rim are well disposed towards openness and are increasingly engaged in the global economy. Secondly, those located on the Atlantic -including the original members of the Southern Common Market (MERCOSUR), midway between ALBA countries and those that maintain FTAs with United States - are somewhat less enthusiastic about openness, although each for different reasons. In this scheme, Brazil would be seen a unique case, given its growing leadership and participation in the global economy, and the size of his domestic market (ECLAC, 2006b, p. 86).

Before going any further, it is worth noting that the divisions described above are in no way rigid, since there is a vast web of communicating links between countries which transcend those divisions. These arise from trade and financial relations, shared interests, membership of different formal groupings such as the Union of South American Nations (UNASUR), the Rio Group, the Latin American System (SELA), the Andean Development Corporation (CAF), and MERCOSUR plus its associate members. There is also one country, Nicaragua, which, through a remarkable juggling act, maintains an FTA with United States and is also a member of ALBA. In addition, all of the region's countries cultivate bilateral relations with Cuba, the major absentee from inter-American forums thus far, but which remains a source of inspiration for many Latin American people, who, among other things, view its resistance to the "empire" as a symbol of great dignity.

Whatever the case may be, this growing division within Latin American and the Caribbean, which, as noted above, was already developing before 2008, was greatly aggravated by the crisis. Thus, the strong tone of condemnation of the "neoliberal model" which accompanied the ALBA discourse (today known as the "Bolivarian Alliance for the Peoples of our America") saw the crisis as the confirmation of its frequent predictions, thereby heralding little less than the demise of capitalism. ${ }^{4}$ That discourse certainly had some objective foundation. The crisis exposed the myth of the exaggerated expectations that the market contained its own mechanisms for selfcorrection against speculation; and it revealed serious

\footnotetext{
${ }^{4}$ In the final communiqué issued by the Special Summit of ALBA, held in Cumaná, Venezuela, on 17 April 2009, the President declared: "Capitalism is killing humanity and the planet. What we are living through is a global economic crisis of a systemic and structural nature, not just one more cyclical crisis." Later on, the text refers to the "decadence of capitalism."
}

failings in regulation and supervision mechanisms in the leading industrialized countries, not to mention the virtual non-existence of regulatory bodies with an international remit. It also noted the huge risk involved in the excessive participation of flight capital in international financial flows.

In addition, the fact that the crisis was born in the "empire" underlined, once again, in the view of the ALBA interlocutors, that this was the source of many of the evils afflicting the region. Consequently, it is hardly surprising that countries that already had serious doubts about the organization of the international economy before the crisis - including their explicit disagreement with the role of the Bretton Woods institutions - now reached the conclusion that all of the failings seen in the workings of the market called for nothing less than a new model. This position contrasted with that of countries that contented themselves simply with accommodating to the situation, even if this meant substantial manoeuvering.

Furthermore, detractor countries believe the crisis provides them with additional vindication, noting that Latin American countries whose export sector is most dependent on the United States market are those that were dragged down most by the effects of recession in that economy. Although it is hard to establish relations of causality between the trend of the United States economy and that of various countries in the region, it is undeniable that the high degree of economic interdependence between the United States and Mexico is one of the factors explaining the dramatic drop in the level of economic activity in the latter country in 2009, even though it showed signs of recovery in the final quarter (ECLAC, 2009e).

That said, in the world of ideas, the crisis is seen as triggering renewed debate in the region on how to approach its development. That debate has features of polarization that call to mind the discussion of the 1960s and 1970s, despite distances in time and considering the huge change of context, on the virtues and disadvantages of centrally managed economies compared to market economies, with "mixed economies" occupying the middle ground, each with its own peculiar nuances. In the globalization context, the extremes are, again in schematic terms, the ALBA agenda on the one hand, and countries that are determined to persevere with the strategy that has prevailed in recent times, without major adjustments, on the other. The other countries - for now the majority having never embraced the "pure" orthodoxy - occupy intermediate spaces in which 
they propose to redefine the frontier between market and State, again with individual variants from one country to another. These countries continue to build on the considerable achievements of recent years as a result of their participation in the global economy, rejecting sudden and substantial course changes in their development strategies. In other words, the current panorama recalls an era that had seemed consigned to the past, in which "opening up" strategies confronted "inward-looking development", or socialism versus capitalism, with reformists occupying the middle ground and attempting to exploit the virtues of both schools of thought while eliminating their inconvenient assumptions.

\section{IV}

\section{Parameters of the debate}

Nonetheless, the content and scope of the opposing strategies still remains unclear. The model that President Hugo Chávez calls "Twenty-first century Socialism" is better defined by what it is not than by what it actually proposes, by categorically rejecting the model it proclaims to be defunct ("neoliberalism"). In the group of countries that are willing to maintain the general course of recent policies, although there is greater clarity about the precise modalities of the liberalization model, the mutations to be incorporated into the model in the future to adapt it to new domestic and international circumstances arising from the crisis are not clear.

In terms of what it actually proposes, the "Bolivarian Alternative" is more doctrinaire than the relative pragmatic liberalization model. In the economic domain, it proclaims solidarity over egotism or profit-seeking; it gives pride of place to the State in preference to private activities; and it argues for inclusion, participation, egalitarianism and poverty reduction as non-renounceable values. In addition, this alternative is wary of an open trade regime guided by market signals and aims to mitigate its effects through balanced trade - sometimes based on a managed trade model between ALBA members and between them and other countries that are not members of the Alliance, which harks back to the Mutual Economic Assistance Council (MEAC) of old. It also values South-South co-operation, one of whose most eloquent specific expressions is the PETROCARIBE Energy Cooperation Agreement promoted by the Government of the Bolivarian Republic of Venezuela, along with bilateral cooperation programmes that both Venezuela and Cuba provide to many countries, particularly in the health area. ${ }^{5}$

\footnotetext{
5 Thus far 18 countries are benefiting from the innovative PETROCARIBE Energy Cooperation Agreement.
}

These general calls for change in both the development paradigm and the international economic order have not yet been articulated in a comprehensive, internally consistent programmatic proposal. In other words, the rhetoric does not yet translate into implementable proposals, as can be inferred from the following quote, which again emphasizes what it is not: "It is necessary to develop an alternative model to the capitalist system; a system of solidarity and complementarity rather than competition; a system that is in harmony with Mother Earth, rather than squandering natural resources; a system of cultural diversity rather than the crushing of cultures and the imposition of cultural values and lifestyles that are foreign to the realities of our countries; a system of peace based on social justice rather than imperialist

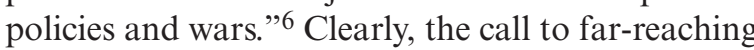
transformation implicit in the foregoing, which encompasses doubtless praiseworthy objectives, also has a significant political and ideological underpinning, and is inspired in a nationalist current and calling for Latin American unity.

At the same time, many of those calls to action, including those related to inclusion, participation and combating absolute and relative inequality, are common to the development strategies of countries that seek to improve their participation in the international economy; so the key element of differentiation between the opposing economic-policy approaches concerns the secular debate on the role of the State and its relation to the market. This, of course, is juxtaposed with more pronounced ideological or doctrinaire differences.

In brief, the region is facing two quite conflicting approaches towards its future development, with a

\footnotetext{
${ }^{6}$ Extracted from the Final Declaration of the Special Summit of ALBA, held in Cumaná, Venezuela, on 17 April, 2009.
} 
wide range of intermediate variants. One end of the spectrum calls for a "fresh start" the precise outlines of which are hard to discern; in contrast, the other extreme accepts that the strategies used to engage in the international economy thus far are pointing in the right direction, although they need constant adjustment, particularly in the wake of the multiple crises of 2008. Any attempt to characterize the conflicting approaches is on slippery ground, not only for the reasons set out in the previous section, but also because each of the region's countries has its own peculiarities in macroeconomic management and social policies, which reflect the prevailing reality and circumstances and also the ideological bias of the government in power.

In any event, the 2008 crisis clearly marks the end of a period in which the vast majority of the region's countries pursued mainstream economic strategies and policies, albeit with variants from one country to another. Some called those economic strategies and policies as "neoliberal", others as the "Washington consensus"; and others still saw them as a national response to the challenges of globalization. Despite considerable nuances, the broad outlines of economic policy in the vast majority of countries were pointing more or less in the same direction. Clearly, the same could be said of the 1950s and 1960s, when the ECLAC paradigm was what constituted the mainstream, and this was called into question by an orthodoxy that started to gain ascendancy in the 1970s, spawning a variety of approaches, similar to the phenomenon being experienced today and which probably will accentuate in the immediate future (Fishlow, 1985).

\section{V}

\section{Conflicting proposals on inequality}

One of the most persuasive critiques of the "neoliberal model" concerns its concentrating and excluding nature. The orthodox thesis whereby "the magic of the market" would ensure that the benefits of economic growth would "trickle down" in favour of low-income groups, has long been discredited. For that reason, over the decades ECLAC has been insisting on the importance of supplementing market signals with specific policies to make growth more equitable. ${ }^{7}$ The social deficits and inequity prevailing in Latin America are also the foundations most widely postulated by those who invoke "Twenty-first century socialism" to address the needs of lower-income groups, pointing to Cuba's undeniable achievements in this area over several decades (ECLAC, 2000).

It is hardly surprising that combating inequality attracts so much attention. As is well known, there is a huge range of literature on absolute and relative poverty in the region, as well as on the strategies for dealing with it and how to reconcile growth and equity objectives. The priority given to this aim does not answer to any specific ideology. Proposals for empowering the poor have even arisen with intellectual origins that can be found in ideas embraced by relatively

\footnotetext{
${ }^{7}$ See, for example, ECLAC (1994b).
}

more conservative groups in the Latin American ideological spectrum - such as placing trust in the functioning of the market, the fundamental role of the rule of law, and an environment that is friendly to small business development. ${ }^{8}$

Latin America and the Caribbean is, on average, the most unequal of all of world's developing regions (World Bank, 2005, pp.4-8 and 66; Lustig, 2009, p.1); and it is also true that, while economic growth tended to help reduce absolute poverty until the 1990 s, in most cases income distribution (relative poverty) tended to stagnate or even worsen (ECLAC, 1997; La Fuente and Sáinz, 2001, pp.161-170). But the fact that this is precisely where changes have occurred in recent times makes a powerful call for reflection at the very least.

It is therefore important to recognize the significant progress made in many of the region's countries, which have pragmatically combined elements of the paradigm in use, particularly in terms of macroeconomic management and strengthening of the rule of law, with innovative policies to deal with the social backlogs

\footnotetext{
${ }^{8}$ See, for example, Commission on Legal Empowerment of the Poor (2008). This commission was co-chaired by Madeleine Albright and Hernando de Soto.
} 
that constitute the main Achilles heel of the region's economic performance. This judicious combination of market and State was starting to yield significant achievements in the region, particularly when comparing certain countries in 2008 , for example, with their situation 10 years earlier. It could also be argued that some nations withstood the devastating effects of the financial and economic crisis with a greater capacity for resistance and greater strength than was envisaged just a few months earlier, at least to judge by performance forecast for 2010 (ECLAC, 2009e).

What is even more relevant for the purposes of this article, however, is that significant progress was made in tackling the social deficits. Thus, the incidence of poverty in the region as a whole fell from around $44 \%$ to $33 \%$ in a decade - between the late 1990s and 2008 - while the incidence of extreme poverty declined from 19\% to 13\% (ECLAC, 2009f, pp. 3-12). Equally or perhaps more significant is that for the first time widespread improvements are reported in the income distribution, which are partly attributable to the compensating effect of public policy on the concentrating trend of growth in earlier periods. ${ }^{9}$ According to a recent ECLAC report, 15 of the 18 countries that have data available reported an improvement in the income distribution (ECLAC, 2009f, pp. 12-17).

According to that report, the progress achieved was due to the following factors among others: firstly, economic expansion combined with growing levels of job creation; secondly, a gradual but significant improvement in the financial capacity of States, which, among other progress, made it possible to achieve a sharp quantitative and also qualitative increase in social spending; thirdly, the application of quite creative distributive policies, such as monetary transfer programs and conditional transfers (Madariaga, 2009); and, fourthly, the favourable (and predictable) effects of the demographic transition under way in most countries of the region, which is producing lower indices of dependency per worker employed (ECLAC, 2009f). Added to these factors are the cumulative effects of increased social spending, particular on education, because the wage gap - which separates the best from the worst paid groups - seems to be narrowing in many countries, as a reflection of that phenomenon (López Calva and Lustig, 2009).

In brief, the development strategies adopted by countries of the region that chose the "openness model", judiciously combining public intervention with market forces, seem to have produced equal or even more satisfactory results in combating poverty and improving the income distribution than those achieved by countries that have been critical of that strategy's notoriously concentrating nature (Lustig and McLeod, 2009). At the same time, it is important to recognize that the impressive progress made in some countries has not been shared by all economies of the region; and capacity to withstand the effects of the crisis was also not generalized.

\section{VI}

\section{Conflicting proposals regarding the international order}

The other subject on which positions within the region are polarized relates to the attitude of the different governments towards the institutional organization of the international economy. Although countries that chose the openness model have expressed serious doubts about the governance systems of existing mechanisms,

\footnotetext{
${ }^{9}$ See, for example, Soares and others (2009, pp. 207-224).
}

they generally argue in favour of correcting those failings through institutional reforms. ${ }^{10}$ In contrast, other countries in the region, led by members of ALBA, propose much more radical reforms and even the replacement of those institutions by something

10 This statement can be confirmed by reviewing some of the documents contained in the web portal of the Inter-governmental Group of Twenty Four (http://www.g24.org/). 
different, which they tend to characterize as more transparent and more democratic. ${ }^{11}$

The dividing line is not clear: all countries in the region denounce the current institutional order; and all of them blame the existing financial institutions, in particular the International Monetary Fund. They all also point to major failings in that international order which depend largely on a single reserve currency (the dollar) and lack many coordination mechanisms. ${ }^{12}$ But the differentiation also has clear features. At one extreme are countries that essentially blame those institutions for "imposing" the model that led to ruin and want to suppress them, transferring their functions to other more democratic and universal institutions such as the United Nations. At the other extreme are countries that have raised a variety of questions about the working practices of those institutions and above all their governance system, but not to the extent of suggesting their elimination. Instead, those countries confine themselves to proposing changes, including major ones, in the governance system and in regulatory practices of those institutions, sometimes considering the creation of new international mechanisms. For example, an idea that is attracting increasing attention is to create an international mechanism to act as a sort of economic governing council for all multilateral organizations in the economic and financial domain. ${ }^{13}$

As a parallel issue, one group of countries severely criticizes the emergence of the Group of 20 (G-20) as an extension of the system of domination and exclusion present in the current international financial order. Other countries in the region accept this informal forum - some of them reluctantly - as a step forward, in that it includes some increasingly protagonist emerging economies, and because it acted swiftly to promote a concerted, coordinated and timely response to the

\footnotetext{
11 "We need to establish a new international economic order based on solidarity, justice, equity and sustainable development. The international financial architecture should be founded anew. The United Nations, particularly this General Assembly, is called to play a key role in this endeavor." MenuAddress by the Minister of Foreign Relations of Cuba, Bruno Rodríguez Parrilla, in the general debate of the 64th session of the General Assembly, 28 September, 2009 (http://www.un.org/ga/64/generaldebate/CU.shtml).

12 José Antonio Ocampo has written an excellent essay on this topic, entitled "Rethinking Global Economic and Social Governance" (Ocampo, 2009).

13 See, for example, United Nations (2009). This commission, chaired by Professor Joseph Stiglitz, among many other things recommended setting up what he calls a "Global Economic Coordination Council, (United Nations 2009, pp. 90-97).
}

crisis. ${ }^{14}$ Moreover, some see this incipient forum as the embryo of a future mechanism such as the economic council described in the foregoing paragraph. Here again, the positions adopted by Latin American and the Caribbean countries to this international dimension of the crisis are highly divergent.

All of these divergences came to the fore during the design, preparation and holding of the United Nations Conference at the Highest Level on the World Financial and Economic Crisis and Its Impact on Development. The mere decision to hold this event was overshadowed by intense controversy between countries that wanted to restore to the United Nations its governing role over international financial and economic organization and those who insisted that that role corresponded to the Bretton Woods institutions and their inter-governmental mechanisms. Underlying the controversy is the increasingly obvious obsolescence of the governance system of the Bretton Woods institutions, particularly in relation to voting weights among their boards of executive directors. In addition, the actual policies of the World Bank, the International Monetary Fund and what now is the World Trade Organization (WTO) were also increasingly called into question. Clearly, the United Nations is not immune from that critique, where there are insistent calls for reform of the Security Council.

The developed countries, led in this case by the United States delegation (in the final months of the Bush administration), ferociously resisted the holding of such a conference. The opposition, in which Cuba, the Bolivarian Republic of Venezuela and Nicaragua, among others, played a proactive role, were equally insistent in favour of it. In the end a compromise was reached at the International Conference on Financing for Development, held in Qatar, Doha, in December 2008, which announced that "the United Nations will hold a conference at the highest level on the world financial and economic crisis and its effects on development". The latter wording was crucial, because countries that denied a role for the United Nations on financial issues did not question its role in promoting development (United Nations, 2008, paragraph 79).

The preparation of the conference was a highly problematic process, especially because it was placed

\footnotetext{
${ }^{14}$ For the report issued by the latest G-20 meeting held in Pittsburgh, United States, on 24 and 25 September 2009, see: https://www. pittsburghg20.org/PDFs/G20Report1109.pdf.
} 
under the aegis of the President of the General Assembly, held at that time by Father Miguel D'Escoto of Nicaragua, who used his position to influence the content of the declaration that would emanate from the General Assembly. The conflicts that soon arose around the final product of the conference were not of the traditional North-South type, but also occurred within the Group of 77 plus China, and among Latin American and Caribbean countries. It is beyond the scope of this article to provide a detailed description of this, but reader should refer to the text of the draft proposal of the policy declaration that the President of the General Assembly submitted to members on 8 May 2009, replacing the "softer" version prepared by the two facilitators he had previously assigned to this task (the Ambassadors of the Netherlands and Saint Vincent and the Grenadines). ${ }^{15}$

That draft declaration projected the conference as an event comparable to the historic Bretton Woods Conference of 1944, and it aimed to place the new financial and monetary order under the universal forum of the United Nations (the "G-192"), in a conceptual and ideological context that did not specifically reflect the viewpoint of the world's leading economic powers, and not even that of many developing countries. There was a rebellion against the text, the President had to retract, and ultimately the conference was held without major upheavals, resulting in a declaration that was diplomatically acceptable to all parties, but irrelevant for future action. ${ }^{16}$

The main point is that the increasing differentiation of approaches on how best to address development has also been transmitted to the positions adopted by the region's countries on economic issues in the main international forums. It remains to be seen whether this new differentiation is healthy for the United Nations. For the moment, it has revived issues that were being debated 35 years ago in the framework of "a new international economic order", with a strong tone of denunciation by countries of the "South" against countries of the "North", and demands to level the playing field of the international economy to give similar opportunities to all countries to participate in its benefits. ${ }^{17}$

\section{VII}

\section{Summary and conclusions}

In conclusion, the 2008 crisis not only had far-reaching repercussions on economies and financing, but also on ideas. The questioning of the paradigm that had been predominant for some two decades, which had gained a growing number of supporters, was intensified as a consequence of the crisis. The many consequences that can be expected for the years to come include the following:

Firstly, it would seem that a period that allowed for a high level of consensus around an economic paradigm, at least in its broad execution outlines, has given way to a period of doubts, questionings, and testing of alternatives.

Secondly, there will consequently be a more intensive debate on development strategies and policies, motivated by the reversal that the crisis has inflicted on many countries. That debate will

\footnotetext{
15 These documents are available on the United Nations portal at: http://www.un.org/ga/president/63/interactive/ uneconference.shtml.
}

be healthy provided it does not lead to unnecessary confrontations between countries or between different groups in any given country.

Thirdly, and as a corollary, new areas are opening up for the work of ECLAC, whose Secretariat can contribute to the debate with its own initiatives and as a vehicle for exchange of opinion and experiences.

Fourthly, at the same time the emergence of the "Bolivarian Alternative", which invokes Latin American and Caribbean unity, paradoxically could foster division rather than rapprochement, by introducing diverging factors within country groupings that have historically been united around common

\footnotetext{
16 General Assembly Resolution 63/303, on the "Outcome of Conference on the World Financial and Economic Crisis and its Effects on Development". The potentially most significant outcome to emerge from the conference was perhaps the establishment of an ad hoc open-ended working group to follow up on the issues contained in the final document (see Resolution 63/305).

17 Resolution 63/224 of 19 December 2008, "Towards a New International Economic Order".
} 
values and interests. It is notable that the Bolivarian Alliance for the peoples of our America has now grown sufficiently to participate in each of the formal integration processes that are currently ongoing: in Central America (Nicaragua), the Caribbean Community (Antigua and Barbuda, Dominica, Saint Vincent and the Grenadines), and in MERCOSUR (should membership by the Bolivarian Republic of Venezuela be ratified). Of course, that scenario will not necessarily be reflected in daily practice, but it does constitute a new reality of differentiation that did not exist before. This in turn is bound to fuel sharper disputes and tensions than those that seen, for example, in the 1990s.

Fifthly, with the increasing differentiation of positions, a new bias of confrontation is being introduced in multilateral forums normally characterized by cooperation. This has made it increasingly difficult to reach universal agreements, as shown by the experience of the High-Level Conference on the
World Financial and Economic Crisis and its Effects on Development in July 2009, and again at the United Nations Conference on Climate Change, where the relatively meagre results — even then rejected by ALBA countries - were being announced just as this article was being completed. ${ }^{18}$

Lastly, as in previous transition periods, it is likely that we are again entering a period of perplexity, in contrast to the relative security that characterized the actions of policymakers in the years leading up to 2008 . This will be another of the legacies of the 2008 crisis.

\footnotetext{
${ }^{18}$ See the Special Communiqué on Climate Change of the VIII ALBA Summit, with a view to the XV Conference of Parties in Copenhagen, on 14 December 2009, and the intervention by the President of the Bolivarian Republic of Venezuela, Hugo Chávez Frías, at the United Nations Conference on Climate Change in Copenhagen, Denmark, on 16 December 2009. http://www. alternativabolivariana.org/.
}

Commission on Legal Empowerment of the Poor (2008), Making the Law Work for Everyone, New York, United Nations Development Programme (UNDP).

ECLAC (Economic Commission for Latin America and the Caribbean) (2009a), Latin America and the Caribbean in the World Economy 2008-2009: Crisis and Opportunities for Regional Cooperation (LC/G.2413-P), Santiago, Chile, August. United Nations publication, Sales No. E.09.II.G.62.

(2009b), La reacción de los gobiernos de las Américas frente a la crisis internacional: una presentación sintética de las medidas de política anunciadas hasta el 31 de agosto de 2009 (LC/L.3025/Rev.4), Santiago, Chile, September.

(2009c), "The real impact of the global economic crisis: a Latin American perspective", opening address of the Executive Secretary at the 2009 Summer School on Latin American Economies (Santiago, Chile, 5 August) [online] http://www.cepal.org/cgi-bin/getprod.asp?xml=/noticias/ paginas/8/33638/P33638.xml\&xsl=/tpl/p18f-st.xsl\&base=/ tpl/top-bottom.xsl

(2009d), El arco del Pacífico latinoamericano después de la crisis: desafios y propuestas (LC/R.2156), Santiago, Chile, November.

(2009e), Preliminary Overview of the Economies of Latin America and the Caribbean 2009 (LC/G.2424-P), Santiago, Chile, December. United Nations publication, Sales No. E.09.II.G.149.

(2009f), Social Panorama of Latin America 2009

(LC/G.2423-P), Santiago, Chile.

(2007a), Economic Survey of Latin America and the Caribbean 2006-2007 (LC/G.2338-P), Santiago, Chile. United Nations publication, Sales No. E.07.II.G.2. (2007b), Preliminary Overview of the Economies of Latin America and the Caribbean 2007 (LC/G.2355-P), Santiago, Chile. United Nations publication, Sales No. E.07. II.G.161.

(2006a), Economic Survey of Latin America and the Caribbean 2005-2006 (LC/G.2314-P), Santiago, Chile. United Nations publication, Sales No. E.06.II.G.2.

(2006b), Latin America and the Caribbean in the World Economy 2005-2006 (LC/G.2313-P), Santiago, Chile, September. United Nations publication, Sales No. E.06. II.G.67.

(2000), La economía cubana: reformas estructurales y desempeño en los noventa, Mexico City, Fondo de Cultura Económica.

(1998), The Fiscal Covenant: Strengths, Weaknesses, Challenges: Summary (LC/G.2024), Santiago, Chile, April.

(1997), Social Panorama of Latin America 1996 (LC/G.1946-P), Santiago, Chile, February. United Nations publication, Sales No. E.97.II.G.4.

(1996), Strengthening Development: the Interplay of Macroand Microeconomics (LC/G.1898/Rev.1-P), Santiago, Chile, July. United Nations publication, Sales No. E.96.II.G.2.

(1994a), Open Regionalism in Latin America and the Caribbean: Economic Integration as a Contribution to Changing Production Patterns with Social Equity (LC/G.1801/Rev.1-P), Santiago, Chile, January. United Nations publication, Sales No. E.94.II.G.3.

(1994b), Social Equity and Changing Production Patterns: an Integrated Approach (LC/G.1701/Rev.1-P), Santiago, Chile, February. United Nations publication, Sales No. E.92.II.G.5. 
(1990), Changing Production Patterns with Social Equity: the Prime Task of Latin American and Caribbean Development in the 1990s (LC/G.1601-P), Santiago, Chile, March. United Nations publication, Sales No. E.90.II.G.6.

Fernández, Fernando (1994), "ECLAC and neoliberalism: an interview with Fernando Fajnzylber", CEPAL Review, No. 52 (LC/G.1824-P), Santiago, Chile.

Fishlow, Albert (1985), "The state of Latin American economics", Economic and Social Progress in Latin America: 1985 Report, Washington, D.C., Inter-American Development Bank.

La Fuente, Mario and Pedro Sáinz (2001), "Participation by the poor in the fruits of growth", CEPAL Review, No. 75 (LC/G.2150-P), Santiago, Chile, December.

López Calva, Luis and Nora Lustig (2009), "The recent decline in inequality in Latin America: Argentina, Brazil, Mexico and Peru", document presented at the Economia Panel Meeting organized by Universidad Torcuato di Tella.

Lustig, Nora (2009), "Poverty, inequality and the new left in Latin America”, Woodrow Wilson Update on the Americas, No. 5, Washington, D.C., Woodrow Wilson International Center for Scholars, October.

Lustig, Nora and Darryl McLeod (2009), Are Latin America's New Left Regimes Reducing Inequality Faster?, Washington, D.C., Woodrow Wilson Center for International Scholars, Latin American Program, July.

Madariaga E., Aldo (2009), Redefiniendo los espacios de la politica social: reducción de la pobreza, transferencias y corresponsabilidades, document presented at the Taller de expertos "Protección social, pobreza y enfoque de derechos: vínculos y tensiones" (Santiago, Chile, 5-6 November 2009).

Ocampo, José Antonio (2009), "Rethinking global economic and social governance", New York, Columbia University, September.

Rossi, Fernando Ramón (2009), “Qué es el ALBA?” [online] http:// www.alternativabolivariana.org, noviembre.

Soares, Sergei and others (2009), "Conditional cash transfers in Brazil, Chile and Mexico: impacts upon inequality", Estudios económicos, Mexico City, El Colegio de México, February.

Torres Olivos, Miguel (2006), "Fernando Fajnzylber: una visión renovadora del desarrollo de América Latina”, Libros de la CEPAL series, No. 92 (LC/G.2322-P), Santiago, Chile, November. United Nations publication, Sales No. S.06. II.G. 124

United Nations (2009), Report of the Commission of Experts of the President of the United Nations General Assembly on Reforms of the International Monetary and Financial System, New York, 21 September.

(2008), Follow-up International Conference on Financing for Development to Review the Implementation of the Monterrey Consensus (A/CONF.212/L.1/Rev.1), New York, December.

World Bank (2005), World Development Report 2006: Equity and Development, Washington, D.C. 